\title{
Burkitt's Lymphoma in a 5 year old Bengali Girl: A Case Report
}

\author{
Chatterjee I', Roy $\mathrm{A}^{2}$ \\ ${ }^{1}$ Dr. Indranil Chatterjee, MBBS. MD. RMO cum Clinical Tutor Department of Pediatric Surgery, ${ }^{2}$ Dr. Arkaprovo Roy, \\ MBBS, Senior Resident, Department of Surgery. Both from R.G.Kar Medical College. Kolkata - 700004.
}

Address for correspondence: Dr. Arkaprovo Roy, E-mail: drarkanatmed1997@gmail.com

\begin{abstract}
Burkitt's lymphoma $(\mathrm{BL})$ is a rare monoclonal proliferation of B-lymphocytes and is classified as a poorly differentiated lymphocytic lymphoma. This tumor was first noted in Africans. The cause of this tumor is debatable, but strong evidence implicates Epstein-Barr virus in its development. This tumor predominantly affects children and is probably the fastest growing tumor in humans, with exuberant proliferation. It is a very rare malignancy accounting for only $0.76 \%$ of solid malignant tumors among Indian children. A case of $\mathrm{BL}$ of the right hemimandible in a 5-year-old Bengali girl is reported.
\end{abstract}

Key words: Burkitt's lymphoma, Immunohistochemistry, Chemotherapy.

\section{Introduction}

ymphomas are a group of malignant tumors - involving cells of the lymphoreticular or immune system such as. Burkitt's lymphoma (BL) is the eponym given to a malignant tumor of the hematopoietic system, characterized by undifferentiated lymphocytes. It is a high-grade aggressive subgroup of non-Hodgkin's lymphoma and is composed of small, noncleaved, diffuse, undifferentiated, malignant cells of B lymphoid origin ${ }^{1}$.

African (endemic) BL (eBL) occurs as a pediatric disease and is almost always associated with EpsteinBarr virus (EBV) exposure. American (sporadic) BL $(\mathrm{sBL})$ occurs in children and adults elsewhere and is less likely to be related to EBV. Patients with human immunodeficiency virus (HIV) also appear to be at risk for developing $B L^{2}$.

\section{Case Report}

A 5 year old girl was referred to us from a peripheral hospital with chief complaints of progressively increasing swelling over right lower jaw with difficulty in degluttition for about a month. She had a history of tooth extraction in the recent past. After that the swelling was increasing in size \& involved whole of the right hemimandible. Teeth became loose and the swelling became prone to bleed. The child also had difficulty in talking and was having occasional dyspnoea.

Patient was alert, conscious \& cooperative with anxious look. She was anaemic but afebrile. Neck veins not engorged, neck glands were not palpable. Respiratory rate was $26 / \mathrm{min}$.

There was a $16 \mathrm{~cm} \times 10 \mathrm{~cm}$ oval shaped mass involving the right hemimandible with venous prominence and shiny skin over it with raised temperature. Intraorally the swelling had irregular ulcerated surface which bled on touching. Tongue was deviated to left with dislocation of few molar and premolar teeth. Liver and spleen were nonpalpable. Lymph nodes at other stations were also impalpable.

Clinically it was thought that this was a case of osteosarcoma of right half of mandible. Other differential diagnoses were fibrous dysplasia of jaw and adamentinoma.

In the mean time there was rapid increase in the size of the swelling with episodic alarming bleeding 
Relevant investigations at the time of admission.

\begin{tabular}{|c|l|l|}
\hline S.No. & Test & \multicolumn{1}{c|}{ Result } \\
\hline 1. & Haemoglobin & $10.9 \mathrm{gm} / \mathrm{dl}$ \\
\hline 2. & Total Leukocyte Count & $8900 / \mathrm{mm}^{3}$ \\
\hline 3. & Differential Leukocyte Count & $\mathrm{N}_{56}, \mathrm{~L}_{42}, \mathrm{E}_{2}, \mathrm{M}_{1}$. \\
\hline 4. & Platelets & $3,20,000 / \mathrm{mm}^{3}$ \\
\hline 5. & Urea & $32.5 \mathrm{mg} / \mathrm{dl}$ \\
\hline 6. & Creatinine & $0.82 \mathrm{mg} / \mathrm{dl}$ \\
\hline 7. & Prothrombin Time & $1.04 \mathrm{sec}, \mathrm{P}-$ Index $-95.5 \%$ \\
\hline 8. & APTT & $29.5 \mathrm{sec}$ \\
\hline 9. & Chest X-ray & NAD \\
\hline 10. & OPG X Ray & $\begin{array}{l}\text { Cyst like SOL in Right side of mandible with displacement of teeth without } \\
\text { any thinning or destruction of cortical boundry favouring Fibrocystic Change? } \\
\text { Fibrous Dysplasia. }\end{array}$ \\
\hline
\end{tabular}

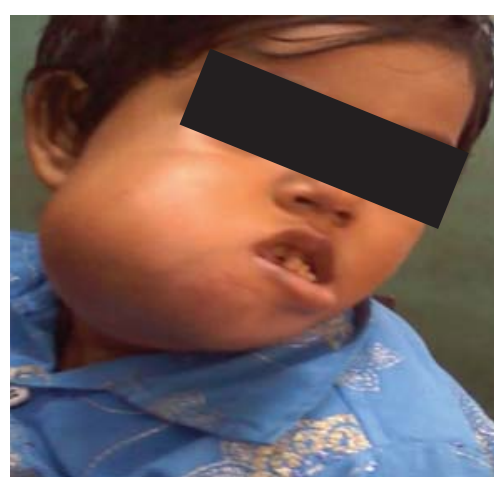

Fig 1: Patient at the time of presentation.

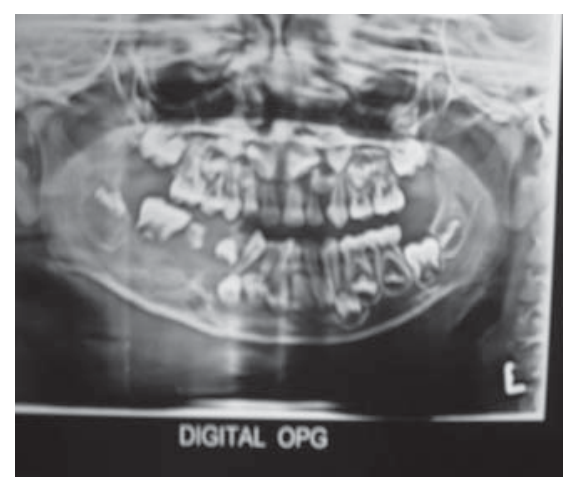

Fig 2: Digital OPG X Ray showing cyst like SOL in the right side of the mandible with displacement of teeth without any thinning or destruction of cortical boundary.

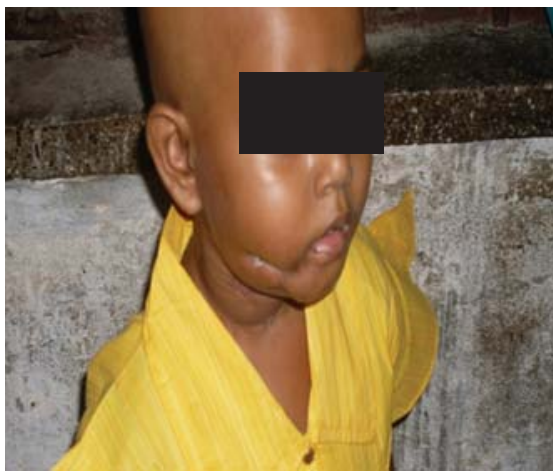

Fig 3: Patient after $4^{\text {th }}$ cycle of chemotherapy. from the intraoral part. Patient underwent tracheostomy followed by bilateral external carotid artery ligation and punch biopsy from the intraoral part of the lesion. Ryle's tube was inserted for enteral feeding.

Histopathology findings revealed diffuse Non Hodgkin's Lymphoma (NHL) high grade, possibly Burkitt's lymphoma.

\section{Chemotherapy was started with following regime:}

Inj. Cyclophosphamide $(500 \mathrm{mg} / \mathrm{m} 2)$ IV on day 1

Inj. Vincristine $(1.5 \mathrm{mg} / \mathrm{m} 2)$ IV on day 1

Inj. Doxorubicine $(50 \mathrm{mg} / \mathrm{m} 2)$ IV on day 1

Syr/ tab Prednisolone (50mg) orally on day 1 to day 5 at 21 days interval for 6 cycles.

The SOL responded dramatically following two cycles of chemotherapy and she was discharged after closure of tracheostoma. At present she is on regular follow up and is doing well.

\section{Discussion}

The sporadic (North American) form of Burkitt lymphoma more commonly has an abdominal presentation (typically pain), whereas the endemic (African) form frequently presents with tumors of the jaw $^{3}$. Endemic Burkitt's lymphoma refers to those cases occurring in African children, usually 4-7 years old, with a male: female ratio of $2: 1$, involving the bones of the jaw and other facialbones, as well as kidneys, gastrointestinal tract, ovaries, breast, and other extranodal sites ${ }^{4}$. Childhood lymphomas with the morphology of Burkitt's lymphoma appear to be uniform with respect to immunophenotype and cytogenetics; this is not true of such lymphomas in adults ${ }^{5}$. Although the immunophenotype of bona fide examples of Burkitt's lymphoma is uniform from case to case, the features of diffuse large B-cell lymphoma are heterogeneous, and a subset of them has an immunophenotype that is the same as that seen in Burkitt's lymphoma ${ }^{6}$.

BL cells are the neoplastic counterparts of a subset of normal activated germinal center B-cells ${ }^{7}$. BL cells express surface $\operatorname{lgM}$ and $\mathrm{B}$-cell-associated antigens 
(CD19, CD20, CD22, CD79a), as well as CD10, HLA-DR, and $\mathrm{CD} 43^{\circ}$. They lack CD5, B cell leukemia/lymphoma 2 (bcl-2), and typically lack CD239. They show nuclear staining for $B$ cell lymphoma 6 (BCL-6) protein, which is independent of bcl- 6 gene rearrangement ${ }^{10}$.

Treatment includes dose-adjusted EPOCH with rituximab ${ }^{11}$. The result of chemotherapy and immunotherapy are excellent. Surgical debulking of large localized jaw or abdominal tumors is beneficial prior to chemotherapy. Cyclophosphamide $40 \mathrm{mg} / \mathrm{kg}$ in a single intravenous administration and repeated about 2 weeks later has given good results. Vincristine and methotrexate are also successful in some cases. A recent report suggests a combination of Cyclophosphamide, vincristine and methotrexate give better results than any single drug.

\section{Conclusion}

Burkitt's lymphoma is a rare, rapidly progressing malignant tumor of childhood with varied clinical features. Its infrequent occurrence among the Indian population should not deter the clinician from including it as a part of differential diagnosis. The importance of good clinical acumen in the early diagnosis of the disease cannot be overemphasized. The present case is a fitting example of the importance of timely diagnosis and prompt treatment which proved to be life saving for the child.

\section{References}

1. DeRossi SS, Garfunkel A, Greenberg MS. Hematologic disease, In: Greenberg MS, Glick $M$, editors., Burkitt's oral medicine diagnosis and treatment, $10^{\text {th }}$ ed. BC Decker: New York; 2003. pp. $429-53$.

2. Choudary VP, Agarwal RK, Marwah RK. Characteristics of Burkitt's lymphoma in India. Indian J Pediatr 1987;54:859-62.

3. Robert M Kliegman, Karen J Marcdante, Hal b Jenson, Richard E Behrman, editors. Nelson's Essentials of Pediatrics. 5th ed.; Philadelphia: Elsevier; 2005. p 740-741.

4. Diebold J. Burkitt lymphoma. In: Jaffe E, Harris $\mathrm{N}$, Stein $\mathrm{H}$ et al., eds. Pathology and Genetics of
Tumours of Haematopoietic and Lymphoid Tissues. Washington, DC: IARC Press, 2001:181-184.

5. McClure RF, Remstein ED, Macon WR et al. Adult B-cell lymphomas with Burkitt-like morphology are phenotypically and genotypically heterogeneous with aggressive clinical behavior. Am J Surg Pathol 2005;29:1652-1660.

6. Gormley RP, Madan R, Dulau AE et al. Germinal center and activated B-cell profiles separate Burkitt lymphoma and diffuse large B-cell lymphoma in AIDS and non-AIDS cases. Am J Clin Pathol 2005;124:790-798.

7. Bellan, C, Lazzi, S, Hummel, M, et al. Immunoglobulin gene analysis reveals 2 distinct cells of origin for EBV-positive and EBV-negative Burkitt lymphomas. Blood 2005;106:1031.

8. Ritz, J, Nadler, LM, Bhan, AK, et al. Expression of common acute lymphoblastic antigen (CALLA) by lymphomas of $B$ cell and $T$ cell lineage. Blood 1981; 58:648.

9. Garcia, CF, Weiss, LM, Warnke, RA. Small noncleaved cell lymphoma: an immunophenotypic study of 18 cases and comparison with large cell lymphoma. Hum Pathol 1986; 17:454.

10. Falini, B, Fizzotti, M, Pileri, S, et al. Bcl-6 protein expression in normal and neoplastic lymphoid tissues. Ann Oncol 1997; 8 Suppl 2:101.

11. Wyndham H. Wilson, Kieron Dunleavy, Stefania Pittaluga, Upendra Hegde, Nicole Grant, Seth M. Steinberg, Mark Raffeld, Martin Gutierrez, Bruce A. Chabner, Louis Staudt, Elaine S. Jaffe, and John E. Janik (2008). "Phase II Study of Dose-Adjusted EPOCH-Rituximab in Untreated Diffuse Large B-cell Lymphoma with Analysis of Germinal Center and Post-Germinal Center Biomarkers". J Clinical Oncol 2007;26(16):2717-2714.

12. Bombay L. Finalize treatment of Burkitt Lymphoma in India under expert surgeons. France In India [serial online] 2010 March-April [cited2010March 23];1(1):[24screens]. Available from: URL:http// www. clubfrancebombay.com/articles/finalizetreatment-of-burkitt-lymphoma-in-india-underexpert-surgeons/.

\section{How to cite this article?}

Chatterjee I, Roy A. Burkitt's Lymphoma in a 5 year old Bengali Girl: A Case Report. J Nepal Paedtr Soc 2011;31(1):61-63. 